\title{
Pathological Observations of the Intestinal Lesions Induced by Caryophyllid Cestodes in Clarias batrachus (Linnaeus) (Siluriformes: Clariidae)
}

\author{
Abu Tweb Abu Ahmed and Muhammad Sanaullah \\ Department of Zoology, University of Dacca, Dacca-2, Bangladesh
}

(Received January 29, 1979)

\begin{abstract}
The comparative histopathology as related to modes of attachment and scolex morphology, gross anatomy, host response and effects of the three caryophyllid cestodes Djombangia penetrans, Lytocestus indicus and $L$. parvulus was studied. Among them $D$. penetrans was found to be most pathogenic and elicited pronounced host reaction in the form of nodules and complete penetration of the intestine followed by $L$. indicus which caused shallow ulcers and mechanical obstruction, and $L$. parvulus caused denudation of the host intestinal tissues. Distribution of the cestodes in the intestine, multiple infections and niche widths as related to scolex morphology, modes of attachment as well as habitats are discussed. Photomicrographs of the species in situ, and of histopathology supplement the observations.
\end{abstract}

The effect of caryophyllids on the vertebrate host has been studied mostly in Europe and the USSR where a common host of caryophyllids, Cyprinus carpio, is raised on a commercial scale. Some of the most significant references to caryophyllids dealing mostly with palearctic species of Caryophyllaeus are: AMLACHER (1961), BAUER (1959), KANAEV (1956), KenNedy and Walker (1969), SchäPERClaus (1954) and SHCHERbaN (1965). Calentine (1962), Calentine and Ulmer (1961), Hunter (1930) and MACKIEwicz et al. (1972) have studied the pathology or the scolex attachment of these parasites.

Fish pathology has generally been a neglected field in the Asia and Far Eastern countries (GopalaKRISHNAN, 1968), although it is in this region that progress in fish culture has been making rapid strides, creating conditions favourable for fish disease to occur more frequently and in epidemic proportions. In Bangladesh a very few attempts have been made to study the parasitic infestations as well as their pathology, moreover the field of cestodes is quite virgin since no work has ever been reported here on the pathogenicity of the parasites especially the caryophyllid cestodes; whereas it is not unworthy to mention that these parasites are severely harmful to Clarias batrachus (Labyrinthic catfish) and possibly a considerable number of bottom feeders including some major carps (AHMED and SanaullaH, 1976), all of which add to economic enterprise of the country.

The present study provides an account of the pathological effects of 3 species of caryophyllids viz: Djombangia penetrans BovieN, 1926; Lytocestus indicus (Moghe, 1925) WoodLAND, 1926 and Lytocestus parvulus FURTADo, 1963.

\section{Materials and Methods}

The host fishes were collected at random during the early September, 1975 to February, 1976 from various physiographic regions under the six different districts of Bangladesh. Live fishes were preserved in 5\% neutral formalin and to ensure rapid preservation of general viscera as well as the parasites therein the host fishes were injected through the abdomen with the same solution. Histological sections of host tissues varying from 4 to 7 microns in thickness were made and stained with haematoxylin and eosin in the usual manner. 


\section{Results}

\section{Djombangia penetrans}

Habitat: Intestine and stomach.

Site of attachment: Generally in the epithelial layer or beyond it.

Mode of attachment: The parasites were found to anchor usually the intestinal villi of the host. They varied in size and shape and some of them were provided with long neck to reach the intestinal wall from a considerable distance due to overcrowding. The density was 8 per sq. cm. (Plate 1A) in maximum case.

In case of abundance they happened to come out of the intestine to exploit the stomach even. The infection was less pronounced in the stomach than in the intestine. The scolices in the mature form of both $D$. penetrans and $L$. indicus were found to be embeded in the muscularies with the rest of the body hanging freely in the lumen. While the larval or premature forms followed the adults of both the species.

Gross findings: Apparently external swellings or nodules were observed on the intestine (Plate 1B). After opening the digestive tract, it was observed that penetration of the parasite resulted in extension of the fibroblast reaction into the serosa causing proliferation of these layers and protuberant curved nodules (Plate 1C). The tunnel through the intestinal wall was often much wider than the neck of the worm, and in some cases semidigested food particles were found in the tunnels and in the body cavity. The scolices and bothrium protruded several millimetres above the intestine surface. The neck damaged, compressed and extensively distrupted the mucosa, submucosa as well as a major portion of muscularies to form a tunnel around it (Plate 1C). Under these prevailing conditions the muscularies disappeared almost totally as a distinct layer due to fusion of fibroblast of adjacent capsules (Plate 1C-dm). Thus the area between the sites of attachment of individuals were also damaged extensively.

Histopathology: The histological changes in the host intestine was correlated with the parasites scolex and the depth of penetration.
This species caused serious pathogenicity as its scolex deeply bored into the serosal layer or beyond it. Thus complete penetration was common as a result the scolex became exposed to the coelom (Plate 1D). In addition to that when the parasites were overcrowding they caused a major destruction of the area of intestine to their vicinity upto $1 / 2$ to $3 / 4$ portion from the rectum, as a result the intestines were observed to be devoided of tissue layers (Plate $1 \mathrm{E}$ and $\mathrm{F}$ ).

The encapsulation response of the host was pronounced with the muscularies becoming thickened through an accumulation of the fibroblastic tissue in the vicinity of the attachment.

\section{Lytocestus indicus}

\section{Habitat: Intestine}

Site of attachment: Throughout the intestinal tract.

Mode of attachment: Similar to the previous species. The density was upto $10 \mathrm{per}$ sq. cm.

Gross findings: No external swellings were observed but it was conspicuously noticed that a considerable portion of the intestine from the rectum was left only with the outer epithelial layer, making it a functionless hollow tract.

This parasite was found to move forward from the posterior portion of the intestine, destroying the tissue layer leaving only the serosal layer (Plate 1E and F).

Histopathology: Usually the scolex penetration was upto the muscularies layer and only in severe pathogenicity it reached upto the serosal layer (Plate 1G), but complete penetration like $D$. penetrans was never observed in this case.

In contrast to the infestations and pathogenicity caused by $D$. penetrans, no fibroblastic capsule or any sort of host response was observed in this case, in spite of an extensive destruction of muscularies by overcrowding of the parasites (Plate $1 \mathrm{H}$ and Plate 2A).

The species caused mechanical obstraction in the gut, occupying a major portion of the lumen (Plate 2B) and leaving a narrow space 
for the chyme to pass through the lumen (Plate 2C). Despite an obstacle by an adult parasite the larval forms also obey the same principles (Plate 2D) as a consequence stands as a total barrier to the chyme. Moreover, under such prevailing conditions the chyme causes mechanical incission through the intestinal wall (Plate 2C), which consequently may cause host mortality.

3. Lytocestus parvulus

\section{Habitat: Intestine.}

Site of attachment: Epithelial to submucosal layer of the intestanal tract.

Mode of attachment: The scolices of the parasite were observed either in adhesion to epithelium or embeded to the epithelium and mucosa.

Gross findings: The intestine was provided with burrows and pores in the crypt. The density was around 10 per sq. cm. No evidence of host response was observed in this case.

Histopathology: An extensive damage in the infected areas were observed. The pathogenicity consisted of a marked denudation of the mucous membrane, disruption of villi and splition of mucosa and submucosa which indirectly affected the muscularies layers to complete damage (Plate $2 \mathrm{E}$ and $\mathrm{F}$ ).

\section{Discussions}

The species studied have different habits and distributions within their habitat, the digestive tract. Most of the species occurred (about $90 \%$ ) in the first and second loop of the anterior part of the intestine. Majority of them characteristically occurred individually, while others occurred in clusturs e.g. $L$. indicus (Plate 2A).

The habitat preference of $D$. penetrans and $L$. indicus in the anterior intestine and $L$. parvulus in the posterior part of intestine was conspicuously noticed. The scolex of former two species particularly of $D$. penetrans was so large that it could function satisfactorily only where the tissue layers are deep enough to accommodate the large scolex particularly of adults, while the latter species which normally penetrates upto the mucosal layer, could adjust anywhere in its habitat, the intestine, despite its preference for the anterior portion. Similar observations were reported by MACKIEWICZ et al. (1972) for some other species of caryophyllids in U.S.A. and Bovien (1926) for $D$. penetrans in Java. MACKIEwICZ et al. (1972) predicted that great variety of scolex types found in caryophyllid cestodes has a direct bearing on the modes of attachment, effects on hosts and, to a certain extent, niche width.

There appears to be an inverse relationship between the scolex adaptions and pathology, as revealed from the present study. Species like $D$. penetrans and $L$. indicus were with unspecialized (blunt) scolices unlike $L$. parvulus. As a result the former two species were more harmful, elicited pronounced host reaction in the form of nodules and shallow ulcers respectively. While the latter species having bothrium or acetabulum caused less harm to the host tissues. In this connection, it can be recalled that strong host response was pronounced only when the parasites af fected the serosal layer, particularly by $D$. penetrans.

The variations in the scolex morphology of the cestodes studied, have drawn interest to investigate into further infestations. Besides specific variations, even $L$. parvulus itself has variable scolices throughout its ages, since it is known that a diverse array of scolex would allow for a greater exploitation of niches through different modes of attachment, as a consequence two or more species would be able to occupy the same position of the intestine, hence allowing multiple infections (MACKIEWICZ et al., 1972). Out of 169 specimens of $C$. batrachus examined during the present study, about $18 \%$ had multiple infections with 2 , and a few with 3 species of cestodes.

The presence of semidigested food materials in the tunnel as well as in the body cavity were also harmful to the host, since a small quantity of partly digested food materials in the body cavity associated with extensive bacterial infection and local inflamation may cause the death of the host (HINE and KEN. 
NEDY, 1974). An instance of fish mortality due to cestodes infection in a tank at Nagpur, India (CHAUHAN and RAMKRISHNAN, 1958) also lends some support to the above observations.

From the foregoing data, the remarkable pathogenicity caused by $D$. penetrans and $L$. indicus in the form of protruding nodules and shallow ulcers respectively; the denudation of tissue layers by L. parvulus, and mechanical obstruction by $L$. indicus has led to draw the conslusion that the caryophyllids may affect their hosts in three ways: (1) Mechanical obstruction of the intestinal tract, particularly in small fish; (2) production of lesions or other pathological conditions; or (3) by causing a general physiological imbalance that may predispose the host to other infections. Under certain conditions any one of these effects may lead to host mortality.

Acknowledgements. We would like to express our sincere gratitude to Dr. John S. Mackiewicz, Professor, Biological Sciences, State University of New York At Albany, U.S.A. for his kind gift of literature and assistance in identification of the species and Prof. S. EGUSA of the University of Tokyo for reviewing the paper. Thanks are also due to Dr. C. R. Kennedy, Department of Biological Sciences, University of Exeter, U.K. for his kind gift of literature. We are also grateful to the Chairman of the Department of Zoology, University of Dacca for providing necessary laboratory facilities while doing the work.

\section{References}

Ahmed, A. T. A. and M. Sanaullah, (1976): Organal and percentage distribution of some metazoan parasites in Heteropneustes fossilis (Bloch) and Clarias batrachus (L.). Journal of the Asiatic Society of Bangladesh, 2 (1), 7-15.

AMLACHER, E. (1961): Taschenbuch der Fischkrankheiten. Jena: Gustar Fischer.

BAUER, O. N. (1959): The ecology of parasites of freshwater fish. In: Parasites of freshwater fish and the biological basis for their control. Bulletin of the State Scientific Research Institute of Lake and River Fisheries 45, 3-215. IPST, Jerusalem, 1962.
Bovien, P. (1926): Caryophyllaeidae from Java. Vidensk. Medd. fra Dansk. Naturh. foren, 82, $157-81$.

Calentine, R. (1962): Archigetes iowensis sp. n. (Cestoda: Caryophyllaeidae) from Cyprinus carpio L. and Limnodrilus hoffmeisteri Claparede. Journal of Parasitology, 48, 513-25.

Calentine, R. and M. Ulmer (1961): Khawia iowensis n. sp. (Cestoda: Caryophyllidae) from Cyprinus carpio L. in Iowa. Journal of Parasitology, 47, 795-805.

Chauhan, B. S. and G. Ramkrishnan (1958): On the occurrence of fish mortality due to helminthic infestation by cestodes cysts in a stocking tank at Nagpur (India). Indian Journal of Helminthology, 10 (1), 53-5.

Gopalakrishnan, V. 1966 (1968): Diseases and parasites of fishes in warm water ponds in Asia and the Far East. Fisheries Reports FAO-UN, 445, 319-43 (Proceedings of the FAO World Symposium on warm water pond fish culture).

Hine, P. M. and C. R. Kennedy (1974): Observations on the distribution, specificity and pathogenicity of the acanthocephalan Pomphorhynchus laevis (Müller). Journal of Fish Biology, 5, 52135.

Hunter III, G. W. (1930): Studies on the Caryophyllaeidae of North America. Ill. Biol. Monog., 11, $186 \mathrm{pp}$.

Kanaev, A. I. (1956): Caryophylliasis in carp and methods of controlling it. Autoreferat, Morsybvtuz, p. 137-49 (in Russain).

KenNEDY, C. R. and P. J. WALKer (1969): Evidence for an immune response by dace Leuciscus leuciscus to infections by the cestode Caryophyllaeus laticeps. Journal of Parasitology, 55, 57982.

Mackiewicz, J. S., G. E. Cosgrove and W. D. Gude (1972): Relationship of pathology to scolex morphology among caryophyllid cestodes. Z. Par. asitenk, 39, 233-46.

SCHÄPERCLAUS, W. (1954): Fischkrankheiten, 3rd edition. Berlin, Akademic Verlag.

Scherban, M. P. (1965): Cestode infections of carp. Kiev. Izdatelstvo "Urozhai".

StiRewalt, M. A. (1963): Chemical biology of secretions of larval helminths. In: H. Whipple ed., some biochemical and immunological aspects of host-parasite relationships. Annals of the New York Academy of Science. 113, art. 1, 36-53. 


\section{Explanations of Plates}

Abbreviations: d, Djombangia penetrans; dm, disappearance of muscle layers; ep, infected epithelial layer as denudated by parasites; es, exposed scolex of $D$. penetrans; $\mathrm{ft}$, fibroblast tissue; $1 \mathrm{p}$, Lytocestus parvulus lv, larva of $L$. indicus; $m$, muscle layers; $n$, nodules; sc, scolex; se, serosal layer; $t$, tunnel.

\section{Plate 1}

Fig. A. Djombangia penetrans in situ.

Fig. B. Intestine with protuberant nodules.

Fig. C. Section through one of the nodules in Fig. B, illustrating scolex of D. penetrans with fibroblast muscle layers adjacent to the tunnel $(\mathrm{t})$.

Fig. D. Intestine with exposed scolex of $D$. penetrans.

Fig. E. Denudated intestine lacking mucosa and sub-mucosal layers.

Fig. F. Infected intestine lacking all but serosal layers.

Fig. G. Mid-sagittal section of $L$. indicus anchored to the intestine, illustrating penetration upto the serosal layer by the unspecialized introvert (scolex).

Fig. H. L. indicus in situ and illustrating the adhesion of scolex to submucosa.

\section{Plate 2}

Fig. A. Attachment of $L$. indicus and their density per sq. $\mathrm{cm}$.

Fig. B. Mechanical obstruction by L. indicus through the lumen of intestine.

Fig. C. . Cross section of the same illustrating the narrow space in the lumen for chyme to pass through, which instantaneously resulted the splition or mechanical incission of the intestine.

Fig. D. Despite the mechanical obstruction by an adult another larva entering into the villi of the host intestine.

Fig. E. L. parvulus destroying tissue layers (epithelial to sub-mucosa) as penetrating through these lyaers.

Fig. F. Ruptured mucosal layers and splitted muscularies due to L. parvulus infection.

\section{胡桃葉条虫 3 種の寄生を受けたナマズ類 Clarias batrachus の腸管の病理学的観察}

\footnotetext{
ナマズ類 Clarias batrachus の腸管に寄生する胡桃葉条虫 3 種 (Djombangia penetrans, Lytocestus indicus, L. parvulus) の各々について, 奇生様式, 頭節の構造, 宿主の反応と影響を解剖学的並びに組織学 的に検討した。D. penetrans は宿主腸壁に瘤状結節の形成をおこし，虫体は腸壁を貫通することから 3 種の うち，最も病害性が強いと考えられた。Lytocestus 属は病害性はやや弱いが，L. indicus は物理的障壁とな る結果，腸管の働きを阻害するとともに寄生部位に浅い潰瘍を形成し，L. parvulus は腸管組織の剝離をひ き起こした。これら条虫の腸管内の分布，混合寄生および寄生の結果生ずる腸壁のくぼみの大きさは条虫の 奇生部位，頭節の形態永よび奇生様式に関連していると考えられた。
} 


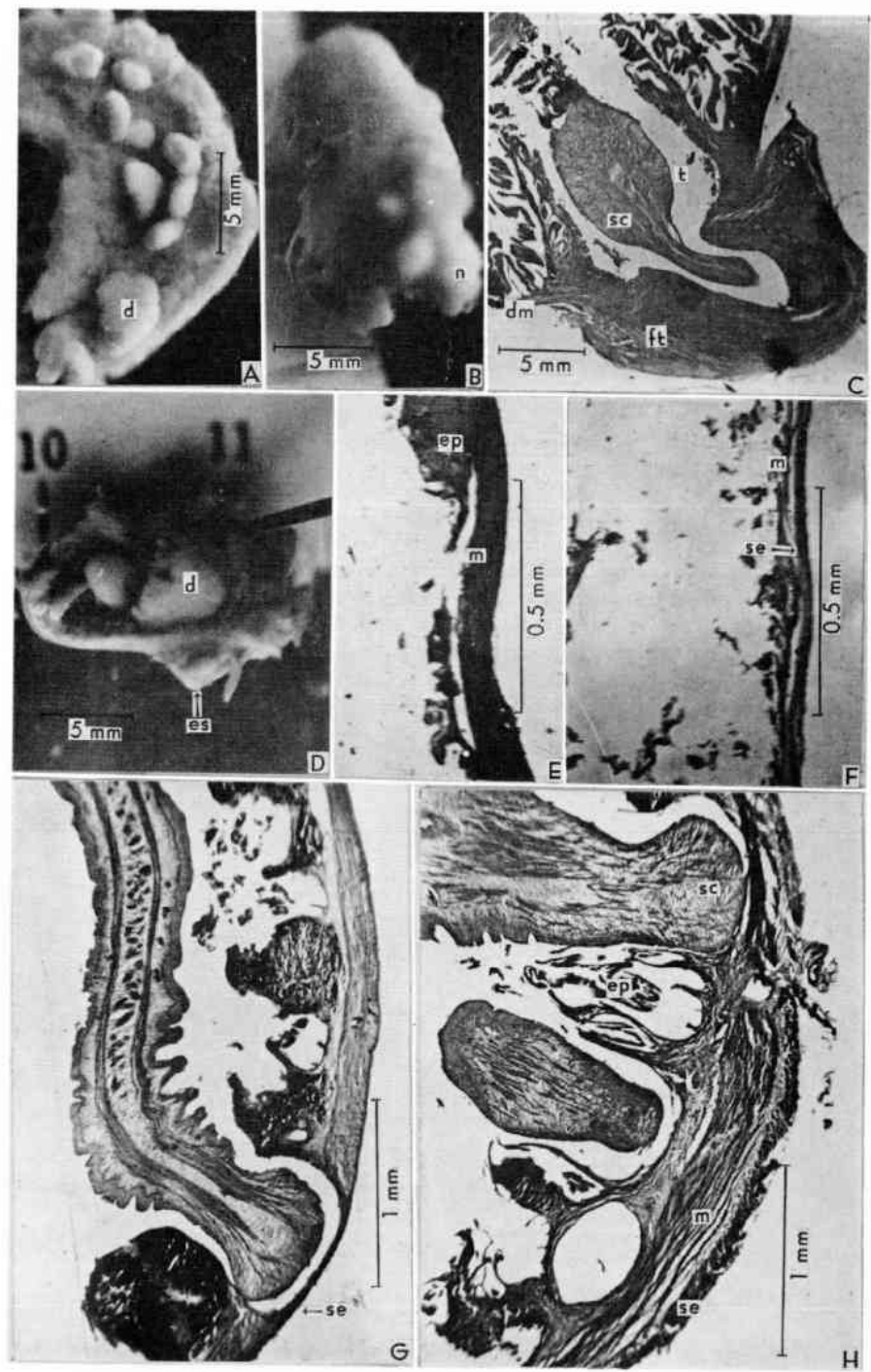

Plate 1 

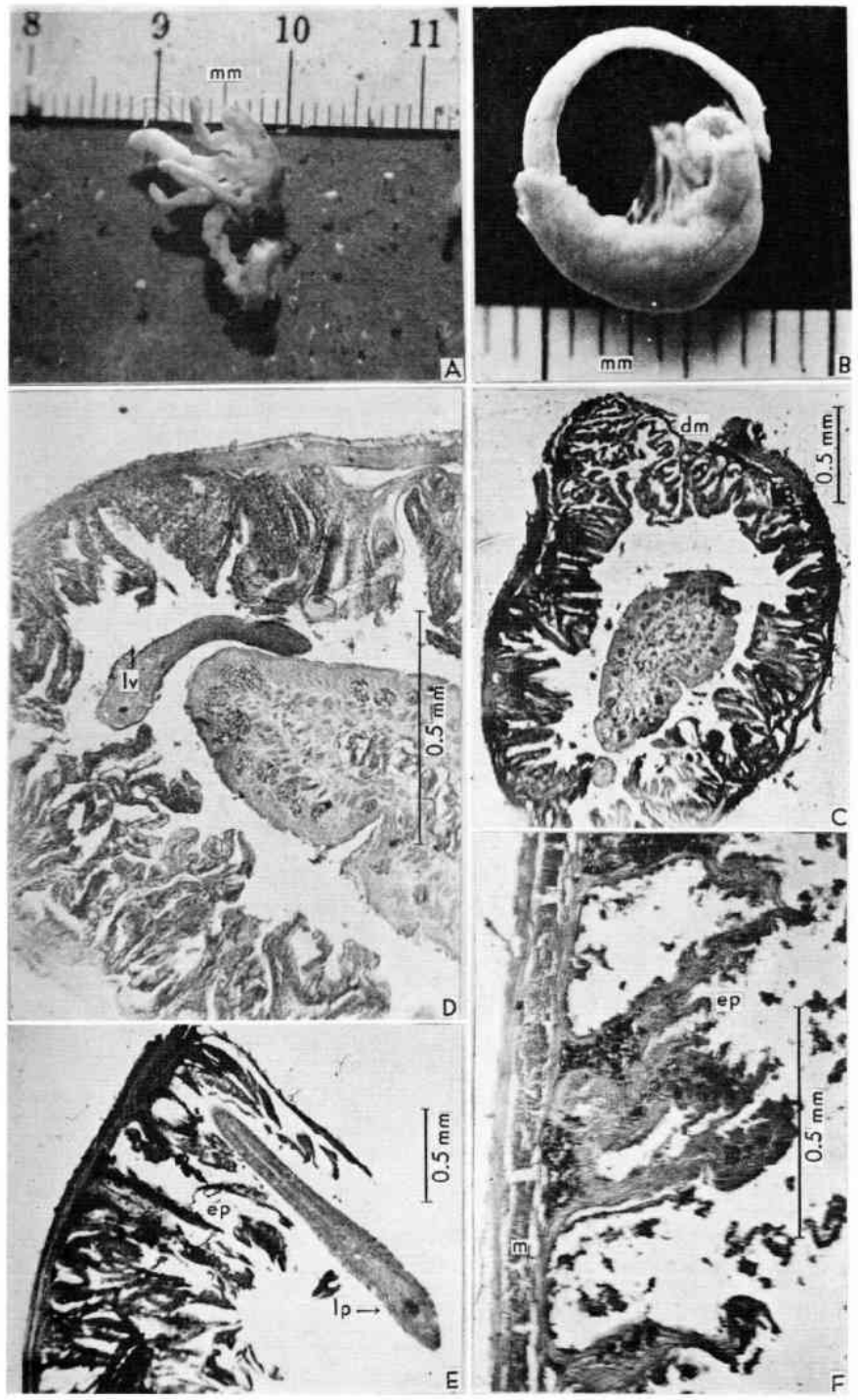

Plate 2 